DOI 10.12737/article_5a82a3b81c0f88.04670041

УДК 633.31:631.55

ТЕХНОЛОГИЧЕСКИЕ ПРИЕМЫ ПОЛУЧЕНИЯ УСТОЙЧИВЫХ УРОЖАЕВ СЕМЯН ЛЮЦЕРНЫ СОРТА САРГА

Валиуллин М.М., Каримов Х.З., Миникаев Р.В.

Реферат. Внедрение прогрессивных технологий возделывания семян люцерны сорта Сарга обеспечивает получение устойчивой урожайности семян в пределах 360 -380 кг/га. Основными элементами этой технологии являются: использование травостоя на семена только 1 год, тщательная подготовка почвы перед посевом, соблюдение глубины заделки семян, правильная организация пчелоопыления, защита посевов от болезней и вредителей, организация поточной обработки семян.

Ключевые слова: люцерна, сорт, урожайность семян, опылители, цветок.

В системе полевого кормопроизводства в настоящее время многолетние травы занимают первостепенное значение. Обусловлено это тем, что корма, полученные из них, биологически полноценны и дешевы. Среди многолетних бобовых трав, выращиваемых в Татарстане, лидирующее место занимает люцерна. Она отличается стабильно высокой урожайностью кормовой массы, засухоустойчивостью, зимостойкостью, отзывчивостью на удобрение, орошение и долголетием. Из нее можно получать корма для многостороннего использования. Кроме того, расширение посевов многолетних бобовых трав является одним из основных путей биологизации земледелия, имеет решающее значение для поддержания баланса гумуса в севооборотах, улучшения агрофизического состояния почвы, повышения плодородия, а также накопления азота в ней. Расширение посевных площадей люцерны сдерживается недостатком семян [Каримов, 2003].

Это вызывает необходимость поиска новых технологических приемов возделывания люцерны на семена. В этом отношении интересным является опыт выращивания семян люцерны сорта Сарга в ООО «Валиуллин M.М.» Пестричинского района. Посевы люцерны на семена размещаются на зернотравяном севообороте, по предшественнику яровой ячмень. Предпочтение отдается открытым южным склонам, на которых обеспечивается хорошая продуваемость посевов и исключается возможность весеннего затопления талыми водами. В тех местах, где имеются ложбины, а весной стоит вода, люцерна обычно погибает от вымокания.

В хозяйстве, если поле имеет сильную засоренность, тогда применяется беспокровный летний посев люцерны. На чистых от сорняков участках предпочтения отдаются посеву под покров ячменя или яровой пшеницы, уменьшая при этом норму высева покровной культуры на 30\%. При беспокровном посеве исключительно большое значение придается тщательной подготовке поверхности почвы перед посевом. Чтобы почва при этом не име- ла комков, а на глубине заделки семян создавалось плотное влажное ложе, предпосевную обработку проводят на глубину заделки семян. Такая мелкая культивация достигается при использовании борон - культиваторов.

В последние годы в хозяйстве широкое распространение нашел сорт Сарга, выведенный селекционером Нагибиным А.С., имеющий хорошую семенную продуктивность.

Посев проводится обычным рядовым способом. Это позволяет уменьшить объем применения гербицидов, тогда как при широкорядном способе посевы обычно зарастают сорняками и требуют многократной химической прополки. Уменьшаются также затраты за счет исключения междурядных обработок. Норма высева 8 -10 кг/га, глубина заделки семян $-1,5-2,0 \mathrm{~cm}$.

Прикатывание почвы до и после посева обязательный прием технологии. В этих целях до посева прикатывают катками 2 ККН $-2,8$, после посева - кольчатыми катками 3 КК - 6 [Каримов, 2006].

Технологический прием прикатывания имеет огромное значение для получения равномерных дружных всходов люцерны, так как увеличение глубины заделки семян этой культуры до 5 см приводит к снижению полевой всхожести до уровня 5 -7 \%.

Учитывая то, что цветки люцерны обычно опыляют одиночные пчелы, а их численность в условиях республики ограниченная, на семенные цели используется не более 20 га на одном участке. Остальную площадь убирают на кормовые цели. Если нужно иметь семенные посевы с площадью 100 га, то размещаются на 5 участках отдаленных от друг друга не менее 1000 м.

Уход за семенными посевами люцерны включает комплекс мероприятий по созданию пищевого, светового режимов, а также борьбы с сорняками.

В хозяйстве широко используется боронование посевов. Так, осеннее боронование в год посева позволяет уничтожить всходы многолетних и зимующих сорняков. Во второй год жизни люцерны весной с периодичностью в 6 
- 7 дней несколько раз боронуют тяжелыми боронами в два ряда. Когда растения достигают высоты 10 - 12 см, участок обрабатывают игольчатыми боронами. Такая обработка полностью очищает участок от сорняков без применения гербицидов, создает благоприятный воздушно-пищевой режим для развития растений люцерны.

В период цветения организуется подвоз медоносных пчел к семенным участкам. Этот прием дает хороший эффект, несмотря на то, что увеличение посевных площадей люцерны на семена способствовало повышению уровня обеспеченности травостоя одиночными пчелами - основными опылителями люцерны.

Важным условием получения устойчивых семян является защита растений люцерны от вредителей. На зерновых культурах при сильном повреждении вредителями потеря урожая может составить $30-50 \%$ от всего объема. На семенных посевах потеря от повреждений вредителями может дойти до 100\%. На практике многих хозяйств такое было. Учитывая все это в ООО «Валиуллин М.М.» организуется интегрированная защита семенных посевов люцерны. Обработка химическими препаратами проводится до цветения и после завершения фазы цветения люцерны.

В хозяйстве принято использование травостоя люцерны на семена только один год. В дальнейшем это травостой используется на кормовые цели. Это обусловлено тем, что на старовозрастных посевах люцерны урожайность сильно снижается.

В зависимости от погодных условий применяются различные способы уборки. Если стоит сухая погода, лучшие результаты дает раздельная уборка. При дождливой погоде или неустойчивых погодных условиях применяется прямая уборка с предварительной десикацией семенного травостоя люцерны.

Созданная механизированная линия по очистке семян люцерны позволяет довести качество семян до требований посевных стандартов, что способствует реализации семян по более высокой цене.

Литература

1. Каримов Х.З. Люцерна на семена в Татарстане/ Х.З. Каримов, Р.Г. Гараев, О.Л. Шайтанов. - Казань, 2003. - 103 c.

2. Каримов Х.3. Повышение семенной продуктивности люцерны/ Х.3. Каримов// Земледелие. - 2006. №3 - С. $10-11$.

Сведения об авторах:

Валиуллин Марат Миннурович - аспирант

Каримов Ханиф Закиевич - доктор сельскохозяйственных наук, профессор

Миникаев Рагат Вагизович - кандидат сельскохозяйственных наук, доцент

ФГБОУ ВО «Казанский государственный аграрный университет», г. Казань, Россия.

\section{TECHNOLOGICAL RECEIPTS FOR PRODUCING SUSTAINABLE YIELDS OF ALFALFA OF SARGA VARIETY}

Valiullin M.M., Karimov Kh.Z., Minikaev R.V.

Abstract. The introduction of advanced technologies for alfalfa seeds cultivation of Sarga variety ensures a stable yield of seeds within 360-380 kilogramm per hectare. The main elements of this technology are the use of grass for seeds for only one year, careful preparation of the soil before sowing, respect for the depth of seeding, proper organization of bee pollination, protection of crops from diseases and pests, and the organization of seed processing.

Key words: alfalfa, variety, seed yield, pollinators, flower.

\section{References}

1. Karimov Kh.Z. Lyutserna na semena v Tatarstane. [Alfalfa on seeds in Tatarstan]. / Kh.Z. Karimov, R.G. Garaev, O.L. Shaytanov. - Kazan, 2003. - P. 103.

2. Karimov Kh.Z. Increase the seed production productivity of alfalfa. [Povyshenie semennoy produktivnosti lyutserny]. / Kh.Z. Karimov // Zemledelie. - Agriculture. - 2006. - №3 - P. 10 - 11.

Authors:

Valiullin Marat Minnurovich - post graduate student

Karimov Khanif Zakievich - Professor, Doctor of Agricultural sciences

Minikaev Ragat Vagizovich - Associate professor, Ph.D. of Agricultural sciences

Kazan State Agrarian University, Kazan, Russia. 